\title{
The Role of Internal Auditors in Achieving the Social Responsibility of the Commercial Banks Operating in Jordan: A Field Study
}

\author{
Faris Al Qadi ${ }^{1} \&$ Mohammed Al Haija ${ }^{2}$ \\ ${ }^{1}$ Faculity of Business, Jerash University, Jerash, Jordan \\ Correspondence: Mohammed Al Haija, Faculity of Business, Jerash University, Jerash, Jordan. E-mail: \\ m_alhaija@yahoo.com
}

Received: March 4, 2021

Accepted: April 1, 2021

Online Published: May 1, 2021

doi:10.5539/ijbm.v16n6p42

URL: https://doi.org/10.5539/ijbm.v16n6p42

\begin{abstract}
The aim of this study is to identify the role of the internal auditors in achieving the social responsibility of the commercial banks operating in Jordan as a result of its affectivity on the sustainable development of the society. The descriptive statistics were used to describe and respond to the two study samples, the ANOVA test and the T-test were used as well at the significance level $(0.05)$ to examine the hypothesis of the study. This study found out that the internal auditors are doing well in verifying the integrity of commercial practices in Jordan regarding the human rights and business behavior on one hand, and don't leave a finger with regard to the safety of environmental and social practices on the other hand. One of the important study recommendations is the necessity of urging the internal auditors to play a pivotal role in monitoring commercial banks related to environment and social relationships by holding training courses and programs in addition to conducting further studies on social responsibility and sustainable development.
\end{abstract}

Keywords: internal audit, social responsibility, sustainable development, commercial banks

\section{Introduction}

\subsection{Introduce the Problem}

Recently, most countries have dramatically interested in following (ISO 26000) issued by the International Organization for Standardization which aims to motivate societies towards sustainable development by focusing on social and behavioral aspects of business organizations and provide guidance not confined exclusively on financial and profitable aspects, because the fact that organizations are inwardly connected with society and its environment. Therefore, this relationship determines effectively the continuity of business organizations and develops its performance for the purposes of continuous growth. Having implemented social responsibility in the business organization, it would have enhanced the society's sight as a result of its social role which in turn generates a community segment adopts this organization and its products to get preference over other organizations that are careless about social aspects even if it is at the expense of increasing the prices sometimes. However, workers and investors who prefer to be loyal to organizations that belong to communities and seek to develop continuously, this will be reflected positively on the financial and economic performance organizations, which are socially committed, compared to other non-committed.

There are many non-profit organizations around the world worked seriously to increase awareness and responsibility towards society either business organizations and productive companies or individuals and consumers. Environmental and human rights organizations considered probably one of the most important organizations that strive to preserve the human right and future generations to live in dignity in societies that are safe socially and culturally.Furthermore, governments have encouraged various companies and organizations to realize the principle of social transparency through accentuating of various activities and social activities in an appropriate manner. For several years, Jordanian companies have taken a social responsibility at internal and external level to meet the needs of preserving the environment, and support qualified human resources correctly in addition to interesting in workers' rights .in emulation It should impose wise founded sovereignty distinguished with transparency andcreate Awareness campaigns as well as social activities at the internal and external levels.

The companies also showed the most important social activities they perform within a period of time in their 
periodic financial reports so thatreporters can get it easily, above all, it could have effectiveness on other financial reports elements that may be turned to instructusers' decisions carried out in future. On the other hand, there is more attention about social activities reports of some Jordanian companies, such as commercial banks in the last two years through further producing of periodic, social and independentreports enjoyed withsocial responsibility which is a media in itself that followers might have a clear vision about the social practices that took place in the company during the period covered by the report, which may lead to increased loyalty belonging to these companies, consequently, it will be exertion to provide media logistically inside the community.

Although the absence of comprehensive editing criteria of social responsibility that tackle its concept, disclosure requirements, reporting, auditing and present its data and limits of the responsibility, some standards addressed aspects of International Environmental Auditing criteria 1010 in relation to environment, Some other matters related to the social aspects keptfor the company management's own estimates, however, this did not exempt the auditor of his responsibility for social activities, especially in light of his primary role in detecting cases of fraud and financial corruption and applying the executive principles in the companies which is charged with audition because of the comprehensive role of the internal auditor in various financial and non-financial activities in companies in general and commercial banks in particular, including social activities through continuous follow-up of various processes and evaluation of procedures to evaluate current performance and guide future work, the studyaimed to state what roleof internal auditors contribute is,to achieve social responsibility of commercial banks operating in Jordan that leads to sustainable development accordingly.

Since early 2016, most countries of the world have begun to implement the sustainable development plan that most of the world gathered in New York City in September 2015, with a historic summit that seeks to fight poverty, respect human rights and preserve the environment. The World Standards Organization (ISO 26000) in 2010 preceded the World Summit by emphasizing social responsibility and its role in achieving sustainable development. Because of the social responsibility of the Jordanian commercial banks as one of the pillars of local development, this study sought to answer the following questions: What is the extent of the internal auditors' contribution to the social responsibility of the commercial banks operating in Jordan? Hence, the following questions may be raised: Is there a role for internal auditors in achieving social responsibility for human rights in commercial banks operating in Jordan? Is there a role for internal auditors in achieving the principles of corporate governance in commercial banks operating in Jordan?

Is there a role for internal auditors in achieving social responsibility for human resources in commercial banks operating in Jordan? Is there a role for internal auditors in achieving business behavior in commercial banks operating in Jordan? Is there a role for internal auditors in achieving environmental responsibility in commercial banks operating in Jordan?

Is there a role for internal auditors in achieving transactions and community relations surrounding commercial banks operating in Jordan?

The importance of the study fountains from the fact that it is a continuation of the previous studies in the field of social responsibility of commercial banks by focusing on the most important elements of (ISO 26000) to achieve sustainable development of commercial banks and society. What makes this study important is the strong connection with more than a beneficiary of the realization of social responsibility in commercial banks; we can describe it as follows:

Community Surrounding Commercial Banks: The achievement of social responsibility will be reflected in the development of society by supportingthe social projects or assisting them with money and objects as well as sponsoring the cultural, scientific and awareness activities that positively affect the members of society.

Customers and Clients of commercial banks: The social contribution of commercial banks is carried with promotional aspects that increase the loyalty of the customers and contributing to attract new customers.

State: The social contributions provided by commercial banks reduce the pressures of society members, whether through social awareness such as the environment or through the assistances provided, and contribute to increase domestic revenues and achieve real economic growth rates.

Employees in commercial banks: preserving the rights of workers and seeking to improve their skills and rehabilitation is an important part of social responsibility.

Investors in commercial banks: Maintaining the wealth of investors from any corruption ormisleading employment practices are an essential part of social responsibility. 


\subsection{Importance of the Problem}

Achieving social responsibility is one of the most important issues pleased by companies and members of societies because of the impact in achieving integrated and comprehensive sustainable development for society all. Thus, the study recognized the role of internal auditors in achieving the social responsibility of commercial banks operating in Jordan. The internal auditors are concerned with the continuous preparation and implementation of various programs, policies and procedures. The detailed objectives of the study in light of (ISO 26000) are to identify the role of internal auditors in achieving the social responsibility for human rights and human resources in commercial banks operating in Jordan and institutional governance in Jordanian commercial banks. Moreover, improving business behavior in commercial banks operating in Jordan and environmental social responsibility of commercial banks operating in Jordan. Last, deals and community relations surrounding the commercial banks operating in Jordan.

\subsection{Describe Relevant Scholarship}

The impression of social responsibility has witnessed many developments as well as fundamental and qualitative changes over the past years because of its association with a society characterized by continuous change in terms of its components and composition. Many scholars have attempted to develop a clear definition of social responsibility, but these definitions remain vulnerable to be changeable continuously. For example, in 1953, Bowen defined corporate social responsibility as an implicit contract between society and the company. Bakri, (2011) defined the company's commitment to the society in which it operates. World Business Council defined it as the continuous commitment done by business owners ethically, moreover, contributing to economic development and ameliorating the situationsof societies. Suhaibani, (2009) and World Bank (2005) defined it as the commitment of economic actors to have contribution to create sustainable development by working with the community to revive the means of living.

Al-Hassan (2014) defines it as the company's commitment to the society in which it operates, by contributing to a wide range of social activities and ethical behavior related to issues of environmental pollution and unemployment, fighting poverty, improving services and solving society's problems. Social responsibility was linked to a set of requirements for achieving sustainable development of society. These requirements were addressed by the International Organization for Standardization and issued a special standard (ISO 26000) that is recorded as a not obligatory voluntary standard consisting of components that auditor must perform currency (Schema, 2012).

Human rights: It concerns with human basic rights including education, housing, and clothing, freedom of relations, political and religious affiliations and protection from apartheid, as well as appreciating human childhood to get living without hard work. Companies' governance: It includes a set of principles that keeps investors' and shareholders' away prejudice; moreover, it provides necessary information transparently and states responsibilities and rewards of management clearly. Human resources: It relates to how to deal with employees, provide the necessary insurance and protection during the course of their work, and work to increase their qualifications by holding courses from time to time and get them involve in conferences and workshops abroad, and encourage employees to build social relations together. Integrity of Business Conduct: represented by the relationship with customers and clients to avoid any corruption or misbehavior, with a view to preventing corruption and avoiding any misbehavior. The relationship with the environment: To include environmental considerations in producing of services to clearrubbish properly, also, work to support and encourage environmental associations and events. Community Relations: It relates to the relationship with the surrounding society through providing social and economic services for development.

Several studies have addressed the subject of (ISO 26000) at many respects, the Lipunga (2016) has identified what extent is companies committed in Malawi with ISO 26000 by analyzing the content of corporate financial reports for the years (2012 and 2013) to confine components that effect commitment to social responsibility. The results showed that there were some social disclosures in the financial reports, which were generally classified as low the disclosure of corporate governance was high, whereas business behavior, the community relationship at the medium level while the environment, human resources and human rights were low. Fuzi et al., (2017) showed that there is a significant relationship between social responsibility practices in accordance with ISO 26000 and the social responsibility performance of Malaysian exportation companies of cars, and the level of performance increases with the application of ISO 26000. Barnes \& Croker (2013) indicated to the role of ISO 26000 on the performance of contractors companies in Hong Kong, the found that many small and medium-sized enterprises consider ISO 26000 irrelevant, while a large number of contractors believe that reputation, legislation, regulation and organizational culture able to improve community responsibility. 
Pfumbi (2014) identified the level of awareness of owners and shareholders and their understanding of the importance of social responsibility in the metal industry in Zimbabwe. The study found that there is a high level of awareness of the importance of social responsibility in achieving sustainable development. The study showed no transparency in the owners involved in decisions. Social responsibility has an essential role in achieving sustainable development in society. Several studies have addressed this important role and have worked to clarify it. Kahwaji \& Ben Hassan, 2016), social responsibility has been defined in achieving sustainable development in business organizations, emphasizing the sustainability of business organizations requires taking environmental and social considerations as part of economic activities and contributing to sustainable development by integrating ethical standards and values into economic practices. This has become a requirement for the continuity of organizations and their success Social gains through the good impression in minds of employees, customers and members of the community.

European Union is constantly trying to push business organizations towards greater social contribution to the sustainable development for all European countries together equally. In Mohammed, (2015) study of social responsibility, it has been defined as a tool that attracts customers and deserves their trust and loyalty in the face of competition among companies (moral responsibility, legal responsibility towards the environment) on customer loyalty. Corporate Social Responsibility (CSR) is associated with a set of subsidiary responsibilities, which has a responsibility towards the human being, whether inside the companies, which is one of the company's important resources that depend on it for its sustainability in terms of suitable, safe and stable environment to ensure its loyalty to the company and carry out its work to the fullest extent. For human rights as an individual, it needs a connection with the company as a recipient or provider of services so that, he is treated in a manner commensurate with various human characteristics he possesses in justice.

The responsibility of the company towards the environment, through the care of the environment and have natural components maintained to protect its balance and deliver to future generations cleanly. The company's responsibility towards the relationship between its owners, management and financiers through judging them fairly through the so-called corporate governance, which has been linked to another responsibility with two dimensions: one of them is internal and the other is external. This responsibility embodies the behavior of businesses in companies to ensure there is no corruption.

Several studies have dealt with these elements through several angles. The study deals with these elements by linking them to the internal auditing whose objectives were related to the objectives of the companies in achieving sustainable development. Despite the lack of previous studies that dealt with the elements of social responsibility together, some dealt with the subject in general. In the study of Senal, et.al., (2012), it shows the role of social responsibility in achieving sustainable development in societies and how to access, as well as the extent of internal auditing contributes to the achievement of social responsibility through the reports being submitted, the role of internal auditing in determining the relative importance ofsocial responsibility, improving corporate value and improving performance. The study showed that sustainable internal auditing is a key element in sustainable development and social expression is linked to business processes and risk management to reflect the quality and quantity of expression transparently.

Shara, (2009) showed the concept of social responsibility in profit organizations, the mechanism of auditing and the role of the auditor in giving a clear picture to interested parties about the organization's responsibility towards society. It is necessary to link social benefits to economic benefits through the investment of sufficient funds for the benefit of society. Florea Florea, (2011) examined the process of planning and implementing internal audit of CSR programs, as other organizations depended on social responsibility programs. Although social responsibility improves the image of the company to customers and increases their attractiveness to them, this is involved with risks though. The study found that the international framework of professional auditing practices dealt with the subject of risks and providing guarantees in favor of companies. Therefore, the study discovered a risk based audit program for social responsibility in companies. In (Weber \& Gerard, 2014), the compliance of business organizations with CSR was discussed to be binding in low and society.

Usually, audition on various social and related activities is usually monitored, in case of any breaches; it will be released without being permanently prevented. Despite of the difficulty in measuring and assessing the breaches, there is a range of difficulties facing social auditing as a societal ethical culture. So, it is a must to overcome difficulties, where it is necessary for the Department to engage in promoting and enabling social activities to be policies, procedures and systems in support of social responsibility compliance. However, the internal audit is not a function of achieving compliance but to check compliance itself. Grigorescu and Hetgan, (2016) tackled the concept of social audition in the Romanian environment in terms of its stages and objectives, as well as the relation between social and accounts audition with social responsibility and sustainable development in the 
business environment. An applied model of social auditing in Romania has emerged.

Several studies have examined the relationship between internal auditing and each component of social responsibility. In relation to the internal audit relationship with the environment, studies have shown that there is a lack of internal auditing for its role in the environment. In the study of Hayek, (2013), it aims to know the extent to which the internal auditors of the Jordanian shareholding companies conducted internal environmental auditing by recognizing their awareness of the importance of internal environmental auditing, the requirements to do so and the challenges they face, Daribati, (2009) examined the role of internal auditing in the evaluation of environmental performance, through the use of questionnaire distributed on a sample of internal auditors and financial managers in Syrian industrial companies. The results showed that internal auditors are not doing the environmental performance assessment and do not have the appropriate qualification, and that the Syrian companies do not abide by their responsibility towards the environment, and there is no any professional or government instructions regarding environmental responsibility.

As for the internal audit link with human resources, there are few studies on this aspect, Mihaela, (2015) shows the role to audit human resources, since social auditing is one of the tools used in human resources management that provides a balance between financial results and social outcomes. Social auditing is an instrument for internal auditors who are working to improve the economic capacity of organizations and contribute to solving the social problems generated by the ever-changing environment. Al-Imam \& Al-Taher, (2013) focused on developing a theoretical framework for auditing human resources which can be done by evaluating the effectiveness and efficiency of policies, procedures and practices used in human resources management and diagnosing the problems that are faced in order to solve them properly. It has been concluded that the application of human resources management audit in organizations helps to optimize the utilization of human capital, reduces the cost of employment and positively affects the performance of human resources functions.

Barghouthi et al. (2013) show the role of internal auditing in monitoring corporate and business behavior in general in order to combat corruption, the study was conducted by internal auditors at the Arab Bank in Jordan that revealed that compliance with international internal audit standards and the role of internal auditor in achieving accountability.

While, Dordevic \& Tadija, (2015) recognizes the role and ability of internal audit to reduce the risk of fraud or embezzlement to detect and prevent it. As for the study of Petraşcu \& Alexandra, (2014), it aims to demonstrate the role of internal audit in the prevention and detection of fraud, highlighting the cases of fraud and preventing them from being committed, while referring to the benefits provided by the internal auditor of the economic unit and the community, and that internal auditing is a function that helps the management to perform its work efficiently, which leads to cost reduction and generating value added and contributes to the fight against fraud. Also Gunduz \& Oytun, (2013) show the fraud and corruption in Turkey's construction industry, one of the main findings was that internal auditing helps reduce fraud and corporate corruption.

As for the relationship of internal audit to corporate governance, Beisland et al. (2015) showed the view of four important external auditors worldwide and many internal auditors of small and medium-sized finance institutions that the presence of internal auditors is more closely linked to governance mechanisms. In their view, there is no relationship between external auditors and governance mechanisms.

Groff, et al., (2016) aims to identify the role of internal auditing in addressing corporate governance problems in light of the continuous development of internal audit function as the internal audit function requires greater independence for the internal auditor. The results showed that the internal audit of corporate governance in a useful way is related to independence and organization. The Slovenian government agreed to the requirement of independence and the Companies Law was issued in 2015, which links the internal audit with a supervisory board that determines their appointments and salaries. El-Kassar et al., (2014) examined the role of internal auditing in strengthening corporate governance through a study of multinational companies operating in Lebanon. The results showed that the quality of internal audit significantly affects corporate governance, especially the audit committee, also maintaining a high level of independence of the internal auditor has an impact on the quality of corporate governance, and that external audit has less impact on governance than on internal audit. The study of Bhasin, (2016) showed that the Audit Committee has a role in applying governance in practice, since the commission acts as the eyes and ears of the Board of Directors, which plays a central role in the detection of fraud and corruption. Many governments considered the Audit Committee enhances confidence and transparency of financial information.

Many of studies dealt with the relationship between accounting and social responsibility on the relationship of accounting in practice to social responsibility and achieving sustainable development, especially that accounting 
is an intellectual audit of the internal audit, and the internal auditing is practiced on the outputs of accounting systems. Alade, Muyiwa E., Nasieku, (2016) found that there is a positive relationship between the functions of accounting and financial reporting and sustainable development, and that the lack of internal flour function may reflect on the reality of investment companies. Dargham et al., (2015) examined the possibility of applying social responsibility accounting by companies listed in Palestine Stock Exchange, by identifying the availability of the components of the application. The questionnaire was distributed to (73) Palestinian companies. One of the most important results is that there is a perception among companies about the concept of social responsibility, but the importance is not given the same proportion of the elements of social responsibility. Human resources are the most important, followed by the environment.

There are also suitable elements for applying social responsibility accounting in companies such as human cadres, legislative structure and accounting systems. The study of Al-armouti, (2013) found the impact of accounting sustainability social elements, environmental elements, economic elements) on financial reporting reports from the perspective of financial managers, accountants and auditors working in industrial companies listed in Amman Stock Exchange by using a sample consisting of 280 respondents. Falaq, (2013) is keen to identify the extent to which Arab oil companies adopted the concept of social responsibility and its impact on society through studying the case of Algerian Sonatrach and Saudi Aramco. The study, after reviewing the financial reports of these companies, found that the support provided by these companies to the society is relatively average, despite the discrepancy in the social performance of each company.

\subsection{Hypotheses and Their Correspondence to Research Design}

In the light of previous studies, reviewed and based on the objectives of the study, the hypotheses of the study can be formulated in a non-specific manner as follows:

H01: There are no statistically significant differences between the opinions of external legal accountants and the directors of departments and branches regarding the role of internal auditors in achieving social responsibility for human rights in the commercial banks operating in Jordan.

H02: There are no statistically significant differences between the opinions of external legal accountants and the directors of departments and branches regarding the role of internal auditors in achieving corporate governance in the commercial banks operating in Jordan.

H03: There are no statistically significant differences between the opinions of external legal accountants and the directors of departments and branches regarding the role of the internal auditors in achieving social responsibility for human resources in the commercial banks operating in Jordan.

H04: There are no statistically significant differences between the opinions of external legal accountants and the directors of departments and branches regarding the role of internal auditors in achieving business behavior in the commercial banks operating in Jordan.

H05: There are no statistically significant differences between the opinions of the external legal accountants and the directors of the departments and branches about the role of the internal auditors in achieving the environmental social responsibility of the commercial banks operating in Jordan.

H06: There are no statistically significant differences between the opinions of external legal accountants and the directors of departments and branches regarding the role of internal auditors in achieving neighboring social transactions of the commercial banks operating in Jordan.

\section{Method}

The Method section describes in detail how the study was conducted, including conceptual and operational definitions of the variables used in the study, Different types of studies will rely on different methodologies; however, a complete description of the methods used enables the reader to evaluate the appropriateness of your methods and the reliability and the validity of your results, It also permits experienced investigators to replicate the study, If your manuscript is an update of an ongoing or earlier study and the method has been published in detail elsewhere, you may refer the reader to that source and simply give a brief synopsis of the method in this section.

\subsection{Community and Sample of the Study}

The study community consists of (402) licensed accountants who are practicing external auditing in Jordan, as well as (13) branch managers and departments in the commercial banks operating in Jordan and listed in Amman Stock Exchange. A simple random sample was selected from each group by (160), ie, the total random sample was (320) respondents. 


\subsection{Measures and Covariates}

The Social Science Statistics Package (SPSS) was used to analyze the collected study data and test hypotheses. The study uses the descriptive analytical methodology, and the sources used in data collection are as follows:

A) Secondary data sources: Including books, studies, Arab and foreign sources related, in paper and electronic.

B) Primary data sources: They are collected through a questionnaire consisting of two groups: the first relates to personal data of respondents, whether they are legal accountants or branch and department managers; the second includes items related to the questions and objectives of the study.

\section{Results}

Table 1. Results of distribution of questionnaire forms

\begin{tabular}{|c|c|c|c|c|c|}
\hline \multirow[t]{2}{*}{ Statement } & \multicolumn{2}{|c|}{$\begin{array}{l}\text { Sample of Certified } \\
\text { Accountants (Auditors) }\end{array}$} & Public & \multicolumn{2}{|c|}{$\begin{array}{l}\text { Sample managers of branches in } \\
\text { commercial banks }\end{array}$} \\
\hline & No. & Percentage & & No. & Percentage \\
\hline Number of distributed forms & 160 & $\% 100$ & & 160 & $\% 100$ \\
\hline Number of recovered forms valid for analysis & 151 & $\% 94.3$ & & 153 & $\% 95.6$ \\
\hline Number of recovered and invalid forms for analysis & 6 & $\% 3.8$ & & 3 & $\% 1.9$ \\
\hline Number of non-recovered forms & 3 & $\% 1.9$ & & 4 & $\% 2.5$ \\
\hline
\end{tabular}

The characteristics of the sample of the study, summarized in table (2) below, which includes a presentation of the characteristics of scientific collection, years of experience and academic specialization, and the number and percentage of each property.

Table 2. Characteristics of the study sample

\begin{tabular}{|c|c|c|c|c|c|}
\hline \multirow[t]{2}{*}{ Statement } & \multicolumn{2}{|c|}{$\begin{array}{l}\text { Sample of Certified } \\
\text { Accountants (Auditors) }\end{array}$} & Public & \multicolumn{2}{|c|}{$\begin{array}{l}\text { Sample managers of branches in } \\
\text { commercial banks }\end{array}$} \\
\hline & No. & Percentage & & No. & Percentage \\
\hline Qualification & 151 & $\% 100$ & & 153 & $\% 100$ \\
\hline Diploma is average and less & 8 & $\% 5.3$ & & 4 & $\% 2.6$ \\
\hline BA & 97 & $\% 64.3$ & & 93 & $\% 60.8$ \\
\hline M.A. & 28 & $\% 18.5$ & & 31 & $\% 20.3$ \\
\hline Ph.D. & 18 & $\% 11.9$ & & 25 & $\% 16.3$ \\
\hline Years of Experience & 151 & $\% 100$ & & 153 & $\% 100$ \\
\hline (5) years and less & 17 & $\% 11.3$ & & 4 & $\% 2.6$ \\
\hline From $(6)$ to $(10)$ years & 68 & $\% 45$ & & 42 & $\% 27.5$ \\
\hline From (11) to (15) years & 52 & $\% 34.4$ & & 82 & $\% 53.6$ \\
\hline More than (15) years & 14 & $\% 9.3$ & & 25 & $\% 16.3$ \\
\hline Academic specialization & 151 & $\% 100$ & & 153 & $\% 100$ \\
\hline Accounting & 113 & $\% 74.8$ & & 69 & $\% 45.1$ \\
\hline Economics and financial and banking sciences & 10 & $\% 6.6$ & & 51 & $\% 33.3$ \\
\hline Business Administration & 28 & $\% 18.6$ & & 31 & $\% 20.2$ \\
\hline Other specialization & 0 & $\%$ & & 2 & $\% 1.4$ \\
\hline
\end{tabular}

Table 2 shows that the highest qualification in both categories is the bachelor's degree. The number of auditors reached (97) respondents by (64.3\%). The number of years of experience (from (6) to (10) years was the largest of the sample of auditors. The number of respondents was (68) by (45\%). As for the years of experience (from 11 to 15 years), the largest was (82) responders by $(53.6 \%)$ and the specialization of respondents, the accounting specialization was the largest in both cases. The number of auditors specialized in accounting was 113 by $74.8 \%$, while the number of managers of branches and departments in commercial banks was 69 by $45.1 \%$ respectively.

Test the validity of the study tool to measure its credibility or internal consistency. A correlation coefficient (alpha-cronbach) was used, with a rule of decision that if the correlation coefficient value was greater than or equal to 0.7 , the items meet the requirement of internal consistency and the results of the study could be generalized to the study population. Table 3 shows the value of correlation coefficient and the achieved condition 
as observed in the items of the study samples. Additionally, Table (4) as shown below that the responses of the study sample are normally distributed.

Table 3. Alpha-Cronbach results

\begin{tabular}{lllll}
\hline Statement & $\begin{array}{l}\text { Sample of } \\
\text { Accountants }\end{array}$ & $\begin{array}{l}\text { Departmental } \\
\text { directors }\end{array}$ & managers and & $\begin{array}{l}\text { Two samples together: certified accountants, } \\
\text { departments and branches managers }\end{array}$ \\
\hline $\begin{array}{l}\text { correlation coefficient } \\
\text { Result }\end{array}$ & 0.82 & 0.79 & 0.83 \\
Consistent & Consistent & Consistent \\
\hline
\end{tabular}

The normal distribution test in order to determine the nature of the statistical test that can be relied upon in order to test the hypotheses of the study, it was necessary to determine whether the responses of the two study samples follow a normal distribution or not. Therefore, Kolmogorov-Smirnove (K-S) Test was used at the significant level $(0.05)$ to confirm the normal distribution. By a decision rule, if the value of the resulting significance level is greater than $(0.05)$, the data distribution is normal.

Table 4. Result of normal distribution test (K-S)

\begin{tabular}{|c|c|c|c|c|c|}
\hline Statement & $\begin{array}{l}\text { Sample of } \\
\text { Accountants }\end{array}$ & Certified & $\begin{array}{l}\text { Departmental managers } \\
\text { directors }\end{array}$ & and & $\begin{array}{l}\text { Two samples together: certified accountants, } \\
\text { departments and branches managers }\end{array}$ \\
\hline Significant level & 0.46 & & 0.27 & & 0.33 \\
\hline Result & Normal & & Normal & & Normal \\
\hline
\end{tabular}

Describe the answers of the study sample: the questionnaire consists of (16) items, which were prepared and divided according to Likert scale. The following degrees were given to the answers: Strongly agree (5), Agree (4), I do not know (3), Diagree (2), strongly disagree (1). The scale was corrected to be (Less than 2.34) is a low degree; (2.34-3.66) is moderate; (3.67 to 5.00) is high result (Beyouk, 2015). The mean and the standard deviation were used to describe the responses of the study sample as presented in tables 5-10 below. The following is a reading of these tables:

A. Describe the responses of the study sample regarding the role of internal auditors in ascertaining the absence of practices that contradict human rights in commercial banks, as shown in Table 5, showing that internal auditors generally perform their role. The total arithmetic mean is (4.53) more than (3.66) and this indicates that the result is positive and high. The table also shows that item (6), which states that "the services provided by the bank are directed to all customers who need them in the community regardless of racism and nationality", achieved the highest average score of 4.95 , with a standard deviation of 0.41 .

Table 5. Human rights in commercial banks

\begin{tabular}{|c|c|c|c|c|}
\hline \multirow{2}{*}{ No. } & \multicolumn{4}{|c|}{$\begin{array}{l}\text { Internal auditors at Jordanian commercial banks make sure that there are no practices or activities that are contrary to human } \\
\text { rights. }\end{array}$} \\
\hline & Items & Average & $\begin{array}{l}\text { Standard } \\
\text { deviation }\end{array}$ & Rank \\
\hline 1 & $\begin{array}{l}\text { Do not use children as employees, employees, or participants in practical tasks } \\
\text { related to the Bank }\end{array}$ & 4.90 & 0.48 & 2 \\
\hline 2 & $\begin{array}{l}\text { The employees of the Bank are practicing their work voluntarily without } \\
\text { coercion }\end{array}$ & 4.42 & 0.62 & 4 \\
\hline 3 & $\begin{array}{l}\text { There is no discrimination between the employees of the bank on the basis of } \\
\text { racism or colors or the geographical area to which they belong. }\end{array}$ & 4.01 & 0.76 & 6 \\
\hline 4 & $\begin{array}{l}\text { There is no pressure on the employees of the bank due to their political } \\
\text { tendencies or partisan loyalties }\end{array}$ & 4.71 & 0.59 & 3 \\
\hline 5 & $\begin{array}{l}\text { There is no discrimination between employees on the basis of religion, } \\
\text { worship, or divine belief }\end{array}$ & 4.19 & 0.69 & 5 \\
\hline \multirow[t]{2}{*}{6} & $\begin{array}{l}\text { The services provided by the bank addressed to all customers who need in the } \\
\text { community without any distinction of racism or nationality }\end{array}$ & 4.95 & 0.41 & 1 \\
\hline & The arithmetic mean of all items & 4.53 & & \\
\hline
\end{tabular}


B) Describe the answers to the study sample regarding the role of internal auditors in ascertaining the application of the principles of corporate governance in commercial banks. Table 6 shows that the internal auditors are in the process of ascertaining and carrying out the necessary procedures. The total arithmetic average was (3.99) more than (3.66) and this indicates a high positive result. The table also shows that item (5), which states "The Board of Directors of the Bank performs its duties within a clear range of powers and responsibilities and the determination of duties for specific allowances and incentives", achieved the highest average of 4.49 and a standard deviation of 0.67 to be in the first rank.

Table 6. Principles of corporate governance in commercial banks

\begin{tabular}{|c|c|c|c|c|}
\hline \multirow{2}{*}{ No. } & \multicolumn{4}{|c|}{$\begin{array}{l}\text { The internal auditors of the Jordanian commercial banks ensure the proper application of the principles of corporate governance } \\
\text { The most important of these are: }\end{array}$} \\
\hline & Items & Average & $\begin{array}{l}\text { Standard } \\
\text { deviation }\end{array}$ & Rank \\
\hline 1 & $\begin{array}{l}\text { The Bank shall take all necessary measures to protect and maintain the funds } \\
\text { of investors and shareholders. }\end{array}$ & 3.98 & 0.98 & 4 \\
\hline 2 & $\begin{array}{l}\text { The treatment of investors and shareholders is done fairly and without } \\
\text { favoring some of them at the expense of others. }\end{array}$ & 3.15 & 1.08 & 5 \\
\hline 3 & $\begin{array}{l}\text { The bank has procedures in place to protect the interests of all relevant parties } \\
\text { such as financiers, depositors, customers and employees. }\end{array}$ & 4.04 & 0.81 & 3 \\
\hline 4 & $\begin{array}{l}\text { The Bank provides information to all users and decision makers in a } \\
\text { transparent and fair manner. }\end{array}$ & 4.28 & 0.71 & 2 \\
\hline \multirow[t]{2}{*}{5} & $\begin{array}{l}\text { The Board of Directors of the Bank performs its duties within a clear range of } \\
\text { powers and responsibilities and assigns duties for specific incentives. }\end{array}$ & 4.49 & 0.67 & 1 \\
\hline & The arithmetic mean of all items & 3.99 & & \\
\hline
\end{tabular}

C) Commercial Banks as shown in Table 7 shows that the internal auditors are in the process of undertaking the necessary actions. The overall average was (3.81) higher than (3.66) and this indicates a high positive value. It is also shown that the item (2), which states that: "the new employee of the Bank is subject to sufficient courses and programs to enable him to perform his duties efficiently", achieved the highest average of 4.75 and a standard deviation of 0.51 to be in the first rank. The arithmetical average of item (7), which states that "the Bank is keen to regulate labor relations between employees leading to continuous improvement of achievement" was at low level, with an average of 2.13 and with a standard deviation of 1.23.

Table 7. Human resources in commercial banks

\begin{tabular}{|c|c|c|c|c|}
\hline \multirow{2}{*}{ No. } & \multicolumn{4}{|c|}{$\begin{array}{l}\text { The internal auditors of the Jordanian commercial banks ensure the proper handling and management with human resources. The } \\
\text { most important of these assertions are: }\end{array}$} \\
\hline & Items & Average & $\begin{array}{l}\text { Standard } \\
\text { deviation }\end{array}$ & Rank \\
\hline 1 & The Bank has a fair system of salaries, bonuses and achievements. & 3.97 & 0.84 & 4 \\
\hline 2 & $\begin{array}{l}\text { The new employee of the Bank is subject to sufficient courses and programs that } \\
\text { enable him to perform his duties efficiently. }\end{array}$ & 4.75 & 0.51 & 1 \\
\hline 3 & $\begin{array}{l}\text { The Bank staff is provided with scientific and practical courses and diplomas to } \\
\text { improve their performance and familiarize them with the latest developments of } \\
\text { work. }\end{array}$ & 4.49 & 0.63 & 2 \\
\hline 4 & $\begin{array}{l}\text { The employees of the bank are involved in conferences and scientific and } \\
\text { professional forums, through which they share their experiences with others } \\
\text { outside the Bank. }\end{array}$ & 3.45 & 0.95 & 6 \\
\hline 5 & $\begin{array}{l}\text { The Bank provides suitable working conditions for various employees in a } \\
\text { manner that helps them to perform their duties and creativity in their business }\end{array}$ & 3.84 & 0.89 & 5 \\
\hline 6 & $\begin{array}{l}\text { The Bank takes appropriate measures to maintain the health and safety of its } \\
\text { employees as part of its human capital, such as life insurance }\end{array}$ & 4.08 & 0.75 & 3 \\
\hline \multirow[t]{2}{*}{7} & $\begin{array}{l}\text { The Bank is keen to organize work relations between employees in a manner that } \\
\text { leads to a continuous improvement of achievement. }\end{array}$ & 2.13 & 1.23 & 7 \\
\hline & The arithmetic mean of all items & 3.81 & & \\
\hline
\end{tabular}


D) Describe the answers of the study sample on the role of internal auditors in verifying the conduct of business in commercial banks. Table 8 shows the internal auditors are in the process of carrying out the necessary procedures. The total arithmetic mean was (4.31) by (3.66) which is high and indicates a high positive result. The table also shows that item (6), which states that "access to the bank's computer screens is carried out in accordance with predefined powers", achieved the highest mean of 4.79 and a standard deviation of 0.52 achieving the first rank.

Table 8: Business behavior in commercial banks

\begin{tabular}{|c|c|c|c|c|}
\hline \multirow[b]{2}{*}{ No. } & \multicolumn{4}{|c|}{ Internal auditors at Jordanian commercial banks verify the proper functioning of the business. The most importantly are: } \\
\hline & Items & Average & $\begin{array}{l}\text { Standard } \\
\text { deviation }\end{array}$ & Rank \\
\hline 1 & $\begin{array}{l}\text { The health and safety of the operations related to providing supplies or rent of } \\
\text { private buildings }\end{array}$ & 4.12 & 0.84 & 5 \\
\hline 2 & $\begin{array}{l}\text { The bank's loan granting decisions are presented to the customers properly and } \\
\text { according to authorized powers. }\end{array}$ & 4.06 & 0.92 & 6 \\
\hline 3 & $\begin{array}{l}\text { The Bank's funding is linked to sufficient guarantees and appropriate guarantees } \\
\text { to be assessed without exaggeration. }\end{array}$ & 4.25 & 0.71 & 4 \\
\hline 4 & $\begin{array}{l}\text { The Bank has a clear mechanism for pricing of liquidated services and } \\
\text { determining the value of commission and interest in advance. }\end{array}$ & 3.78 & 1.05 & 7 \\
\hline 5 & $\begin{array}{l}\text { The bank uses a computer system that has sufficient protection to prevent its } \\
\text { penetration or manipulation by any external hacker }\end{array}$ & 4.62 & 0.58 & 2 \\
\hline 6 & $\begin{array}{l}\text { Access to the bank's computer screens is done in accordance with predefined } \\
\text { powers }\end{array}$ & 4.79 & 0.52 & 1 \\
\hline \multirow[t]{2}{*}{7} & $\begin{array}{l}\text { The bank has adequate procedures and means to protect cash from theft, theft or } \\
\text { loss }\end{array}$ & 4.54 & 0.62 & 3 \\
\hline & The arithmetic mean of all items & 4.31 & & \\
\hline
\end{tabular}

E) Describe the answers to the study sample regarding the role of internal auditors in ensuring the proper handling of environment in commercial banks. Table 9 shows that the internal auditors do not perform their role and the necessary procedures adequately. The value of the total arithmetic mean was (2.29), which is a low value, less than (2.33), indicating that the required positive role is not taken. The table also shows that item (5), which states: "Bank employees initiate humanitarian activities and practices for community service such as blood donation." The highest rank was achieved with the highest average of 3.03 and a standard deviation of 1.35.

Table 9. Community relations surrounding commercial banks

\begin{tabular}{|c|c|c|c|c|}
\hline \multirow[t]{2}{*}{ No. } & \multicolumn{4}{|c|}{$\begin{array}{l}\text { Internal auditors in Jordanian commercial banks verify the good practices of the community with the surrounding communities. } \\
\text { The most important of them are: }\end{array}$} \\
\hline & Items & Average & $\begin{array}{l}\text { Standard } \\
\text { deviation }\end{array}$ & Rank \\
\hline 1 & The Bank provides support to poor families, orphanages and the elderly. & 1.19 & 1.73 & 6 \\
\hline 2 & $\begin{array}{l}\text { The Bank contributes to the promotion of scientific and social activities in surrounding } \\
\text { schools and universities. }\end{array}$ & 2.87 & 1.22 & 2 \\
\hline 3 & The Bank plays a positive role by attending national events and celebrations & 2.37 & 1.04 & 3 \\
\hline 4 & $\begin{array}{l}\text { The Bank participates in the work and support of social awareness campaigns that take } \\
\text { place in different geographical areas, especially the least and most caring }\end{array}$ & 2.28 & 1.31 & 4 \\
\hline 5 & $\begin{array}{l}\text { Bank employees initiate humanitarian activities and practices to serve the community, } \\
\text { such as blood donation }\end{array}$ & 3.03 & 1.35 & 1 \\
\hline \multirow[t]{2}{*}{6} & $\begin{array}{l}\text { The Bank sponsors and encourages youth in schools and universities by adopting their } \\
\text { talents and motivating them to innovate }\end{array}$ & 2.05 & 1.45 & 5 \\
\hline & The arithmetic mean of all items & 2.29 & & \\
\hline
\end{tabular}

Test the hypothesis of the study statistically, since the distribution of response groups of the study samples follow the normal distribution, the study used (ANOVA) (P) at the significant level of (0.05) with a rule of 
decision stating that "if the value of $(\alpha)$ is less or equal to (0.05), the null hypothesis is accepted and there is no difference of statistical significance, and rejecting the alternative hypothesis that states there are statistical significant differences.

To determine the opinion of each sample of the study samples and the response directions, the $\mathrm{T}$ test was used at the significant level of $(0.05)$ with the rule if the value of $(\alpha)$ is less than or equal to $(0.05)$ The role of internal auditors, and if greater than (0.05), the answers of one sample are negative and indicates the lack of role. Therefore, the hypothesis of the study can be tested as follows:

A) To test the hypothesis of the first study, which states that "there are no significant differences between the opinions of external legal accountants and directors of departments and branches about the role of internal auditors in achieving social responsibility for human rights in commercial banks operating in Jordan." Table 10 presents the result of the hypothesis test, which shows that there are no differences because the level of significance $(\mathrm{P})$ is $(0.002)$ which is less than $(0.05)$, i.e. there is an agreement between the two study samples. This is because the value of the significance of $(t)$ from the point of view of legal accountants is $(0.029)$ and it is $(0.019)$ from the point of view of the managers of the departments and branches, both results are less than $(0.05)$.

Table 10. Result of hypothesis of the first study

\begin{tabular}{|c|c|c|c|}
\hline Statement & $\begin{array}{l}\text { Test of variance (P) between legal } \\
\text { accountants and departmental and } \\
\text { branch managers }\end{array}$ & $\begin{array}{l}\text { Test (T) from the } \\
\text { perspective of certified } \\
\text { accountants }\end{array}$ & $\begin{array}{l}\text { Test (T) from the perspective of } \\
\text { department and branch managers }\end{array}$ \\
\hline $\begin{array}{l}\text { Level of } \\
\text { significance }\end{array}$ & 0.002 & 0.029 & 0.019 \\
\hline Result & There are no differences & There is a role & There is a role \\
\hline
\end{tabular}

B) Refer to the hypothesis of the second study, which states that "there are no statistically significant differences between the opinions of external legal accountants and directors of departments and branches about the role of internal auditors in achieving corporate governance in commercial banks operating in Jordan." Table 11 below presents the result of the hypothesis test. It is shown that there are differences because the level of significance $(\mathrm{P})$ is 0.072 , which is greater than (0.05). There is no agreement between the two study samples. The belief of legal accountants that there is no role is because the value of the significance of $(t)$ from the point of view of the chartered accountants $(0.061)$ which is greater than $(0.05)$, and from the point of view of the managers of the Chambers and Branches, the value of $(\mathrm{T})$ is $(0.028)$ and the value of significance $(\mathrm{T})$ is less than $(0.05)$.

Table 12. Result of hypothesis of the second study

\begin{tabular}{llll}
\hline Statement & $\begin{array}{l}\text { Test of variance }(\mathrm{P}) \text { between legal } \\
\text { accountants and departmental and } \\
\text { branch managers }\end{array}$ & $\begin{array}{l}\text { Test }(\mathrm{T}) \text { from the perspective } \\
\text { of Chartered Accountants }\end{array}$ & $\begin{array}{l}\text { Test }(\mathrm{T}) \text { from the perspective of the } \\
\text { directors of the departments and } \\
\text { branches }\end{array}$ \\
\hline $\begin{array}{l}\text { Level of significance } \\
(\alpha)\end{array}$ & 0.072 & 0.061 & 0.028 \\
Result & There are differences & There is no role & There is no role \\
\hline
\end{tabular}

C) To test the hypothesis of the third study, which states that "there are no significant differences between the opinions of external legal accountants and directors of departments and branches about the role of internal auditors in achieving social responsibility for human resources in commercial banks operating in Jordan." Table 12 below presents the result of the hypothesis test, which shows differences because the level of significance (P) is 0.065 , which is greater than $(0.05)$.

There is no agreement between the two study samples. The belief of legal accountants that there is no role is because the value of $(t)$ from the point of view of the certified accountants is $(0.094)$ which is greater than $(0.05)$, and from the point of view of the managers of the Chambers and Branches, the value of $(\mathrm{T})$ is $(0.045)$, the value of significance $(\mathrm{T})$ is less than $(0.05)$. 
Table 13. The result of the hypothesis of the third study

\begin{tabular}{|c|c|c|c|}
\hline Statement & $\begin{array}{l}\text { Test of variance }(\mathrm{P}) \text { between legal } \\
\text { accountants and departmental and branch } \\
\text { managers }\end{array}$ & $\begin{array}{l}\text { Test }(\mathrm{T}) \text { from the perspective of } \\
\text { Chartered Accountants }\end{array}$ & $\begin{array}{l}\text { Test }(\mathrm{T}) \text { from the point of } \\
\text { view and the directors of the } \\
\text { departments and branches }\end{array}$ \\
\hline $\begin{array}{l}\text { Level of significance } \\
(\alpha)\end{array}$ & 0.065 & 0.094 & 0.045 \\
\hline Result & There are differences & There is no role & There is role \\
\hline
\end{tabular}

D) Test the hypothesis of the fourth study, which states that "there are no significant differences between the opinions of external accountants and directors of departments and branches about the role of internal auditors in the conduct of business behavior in commercial banks operating in Jordan." Table 13 presents the result of the hypothesis test. It shows that there are no differences because the level of significance $(P)$ is $(0.019)$, less than $(0.05)$. There is an agreement between the two study samples. This is because the value of the significance $(\mathrm{t})$ from the perspective of the certified accountants is $(0.041)$ and from the perspective of directors of the Chambers and Branches is $(0.027)$, both results are less than $(0.05)$.

Table 14. Result of the fourth hypothesis

\begin{tabular}{llll}
\hline Statement & $\begin{array}{l}\text { Test of variance }(\mathrm{P}) \text { between legal } \\
\text { accountants and departmental and branch } \\
\text { managers }\end{array}$ & $\begin{array}{l}\text { Test }(\mathrm{T}) \text { from the perspective of } \\
\text { Chartered Accountants }\end{array}$ & $\begin{array}{l}\text { Test }(\mathrm{T}) \text { from the point of } \\
\text { view and the directors of the } \\
\text { departments and branches }\end{array}$ \\
\hline $\begin{array}{l}\text { Level of significance } \\
(\alpha)\end{array}$ & 0.019 & 0.041 & 0.027 \\
Result & There are differences & There is a role & There is a role \\
\hline
\end{tabular}

E) Test the hypothesis of the fifth study, which states that "there are no significant differences between the opinions of external legal accountants and the directors of departments and branches about the role of internal auditors in achieving environmental social responsibility of commercial banks operating in Jordan." Table 14 presents the result of the hypothesis. It shows that there are no differences, because the level of significance $(\mathrm{P})$ is 0.047 , less than 0.05 . There is an agreement between the two study samples. $(0.073)$, which is greater than (0.05), and that from the perspective of the managers of departments and branches, the value of significance $(\mathrm{T})$ is $(0.061)$, which is greater than $(0.05)$, meaning that there is no role from their perspective.

Table 14. Result of the test hypothesis of the fifth study

\begin{tabular}{llll}
\hline Statement & $\begin{array}{l}\text { Test of variance }(\mathrm{P}) \text { between legal } \\
\text { accountants and departmental and branch } \\
\text { managers }\end{array}$ & $\begin{array}{l}\text { Test }(\mathrm{T}) \text { from the perspective of } \\
\text { Chartered Accountants }\end{array}$ & $\begin{array}{c}\text { Test }(\mathrm{T}) \text { from the point of } \\
\text { view and the directors of the } \\
\text { departments and branches }\end{array}$ \\
\hline $\begin{array}{l}\text { Level of significance } \\
(\alpha)\end{array}$ & 0.047 & 0.073 & 0.061 \\
Result & There are differences & There is no role & There is no role \\
\hline
\end{tabular}

F) Test the hypothesis of the sixth study, which states that "there are no significant differences between the opinions of external legal accountants and directors of departments and branches about the role of internal auditors in the realization of community transactions surrounding commercial banks operating in Jordan." Table 15 below presents the result of the hypothesis test. It shows that there are no differences because the level of significance $(\mathrm{P})$ is 0.039 , less than $(0.05)$. There is an agreement between the two study samples. $(0.104)$, which is greater than (0.05), and that from the perspective of departments and branches perspective, the value of the significance $(\mathrm{T})$ is $(0.74)$, which is greater than $(0.05)$, meaning that there is no role from their perspective. 
Table 15. Result of the hypothesis test of the sixth study

\begin{tabular}{llll}
\hline Statement & $\begin{array}{l}\text { Test of variance }(\mathrm{P}) \text { between legal } \\
\text { accountants and departmental and branch } \\
\text { managers }\end{array}$ & $\begin{array}{l}\text { Test }(\mathrm{T}) \text { from the perspective of } \\
\text { Chartered Accountants }\end{array}$ & $\begin{array}{l}\text { Test }(\mathrm{T}) \text { from the point of } \\
\text { view and the directors of the } \\
\text { departments and branches }\end{array}$ \\
\hline $\begin{array}{l}\text { Level of significance } \\
(\alpha)\end{array}$ & 0.039 & 0.132 & 0.074 \\
Result & There are no differences & There is no role & There is no role \\
\hline
\end{tabular}

\section{Conclusion}

The aim of this study is to identify the role of internal auditors in achieving the social responsibility of the commercial banks operating in Jordan because of their impact on reaching the sustainable development of the society. A questionnaire was prepared for the study, which included the elements of social responsibility covered by ISO 26000, which relate to human rights, corporate governance, human resources, business behavior, environment and community relations. The questionnaire was distributed to two random samples, the first of which consisted of (151) external legal accountants (auditors) and the second of 153 branch managers in commercial banks operating in Jordan. The descriptive statistics were used to describe the study sample and the answers, the ANOVA test and the $\mathrm{T}$ test were used at the significance level $(0.05)$ to test the hypothesis of the study.

The results of this study found that the external auditors, departmental managers, and branch managers believe that internal auditors are doing their part to verify the soundness of business practices in Jordan related to human rights and business behavior, and that this result is consistent with (Dordevic \& Tadija, 2015), (Petraşcu \& Alexandra, 2014); and that they do not play their part in verifying the integrity of commercial bank practices related to the environment and community relations, which is consistent with the study of (Hayek, 2013; Deribati, 2009). The sample of branch and departmental managers only sees a role for internal auditors in monitoring commercial bank practices related to corporate governance and human resources. This is in line with the study of (Mihaela, 2015) and the auditors do not see the role of auditors in following up on commercial bank practices, institutional governance and human resources. In light of the previous results, the study recommends encouraging internal auditors to play a role in monitoring the practices of commercial banks operating in Jordan related to environment and community relations. Conducting courses and training programs for internal auditors and employees of commercial banks related to social responsibility in the light of (ISO 26000), raising the awareness of the importance of social development for commercial bank employees because they have a link to achieving a sustainable development of society and conducting further studies on social responsibility and sustainable development. It has an impact in guiding the attention of all members of society to work towards achieving and reaching it.

\section{References}

Al-Armouti, A. A. (2013). The Impact of Sustainability Accounting on Financial Reporting Reports in Jordanian Joint Stock Companies in the Amman Stock Exchange, Unpublished Master Thesis, Middle East University, Jordan.

Al-Hassan, B. (2014). The role of social responsibility in improving the performance of the organization - a case study of the Naftal Foundation, unpublished memorandum for the master's degree, Mohammed Khudair University - Biskra, Algeria, 2014.

Al-Hayek, A. F. K. (2013). Environmental Internal Auditing in the Jordanian Industrial Joint Stock Companies. Studies, Management Sciences, 40(2), 394.

Bakri, T. Y. (2001). Marketing and Social Responsibility, Dar Wael Publishing and Distribution, Amman (Jordan) (1st ed.).

Barghouthi, S., Saleh, A. N., \& Karim, A. A. J. (2013). The Role of the Internal Audit Agency in Disclosure of Corruption through Accountability. Journal of Accounting and Financial Studies, 8(2).

Dargham, M. M., Mohammed, S. L., \& Baha, A. D. A. A. (2010). The extent to which social responsibility accounting can be applied by companies listed on the Palestine Stock Exchange. Al-Azhar University Journal, Gaza, Human Sciences Series, 1(5), 215.

Dribati, R. F. (2009). Role of Internal Auditing in Environmental Performance Assessment. Unpublished Master Thesis, Tishreen University, Syria, 2009. 
Fallah, M. (2013). Corporate Social Responsibility for the Arab Oil Companies "Sonatrach Algerian and Saudi Aramco" model. Journal of the researcher, 12, 29.

Imam, M., Adam, M., \& Tahir, A. M. A. (2013). Towards a Framework for Human Resources Auditing. Journal of Economic Sciences, 14, 1.

Maki, H., \& Bouteiba, A. R. (2014). Role of Social Responsibility for Economic Institutions in Achieving Sustainable Development - EU Model. National Conference on the Role of Social Sciences in Development in Algeria. Tiaret, Algeria.

Mohamed, N. A. (2015). The Impact of Corporate Social Responsibility on Customer Loyalty. Unpublished Master Thesis, Sudan University of Science and Technology, Sudan, 2015.

Shara, M. (2015). External Audit Data on the Social Responsibility of Profit Organizations. Journal of Economic and Financial Sciences, 15(53), 288.

Suhaibani, S. (2009). Social responsibility and its role in the participation of the private sector in development: an applied case to the Kingdom of Saudi Arabia. International Conference on the Private Sector in Development: Assessment and Prospects, Beirut.

\section{Copyrights}

Copyright for this article is retained by the author(s), with first publication rights granted to the journal.

This is an open-access article distributed under the terms and conditions of the Creative Commons Attribution license (http://creativecommons.org/licenses/by/4.0/). 